\title{
O AUTORIMA
}

\section{BIRT, DANIJELA, prof.}

Rođena je 1981. godine u Bjelovaru. 2005. diplomirala je povijest i etnologiju na Filozofskom fakultetu u Zagrebu. Tijekom studija od 2001. do 2005. sudjelovala je u projektu dr. sc. Milane Černelić Identitet i etnogeneza primorskih Bunjevaca. 2004. sudjeluje u međunarodnom projektu The Politics and Poetics of Place. U razdoblju 2005. - 2006. godine bavila se terenskim istraživanjima u sklopu međunarodnoga projekta KASS - Kinship and Social Security. Od 2006. zaposlena je kao asistentica na Odjelu za etnologiju i kulturnu antropologiju Sveučilišta u Zadru. Potkraj 2007. upisala je poslijediplomski doktorski studij etnologije i kulturne antropologije na Odjelu za etnologiju i kulturnu antropologiju na Filozofskom fakultetu u Zagrebu. Uže područje znanstvenog interesa su teme iz društvenoga života (običaji, obiteljski rituali), zatim vjerovanja i prakse vezane u vještice i magiju kao dio popularnih sustava znanja.

\section{BOGOVIĆ, MILE, mons. dr. sc.}

Rođen je u Slunju 1939. godine. Teologiju je studirao u Pazinu i Zagrebu, a crkvenu povijest na Sveučilištu Gregoriana u Rimu gdje je i doktorirao 1971. godine, obranivši tezu "Katolička Crkva i pravoslavlje u Dalmaciji za vrijeme mletačke vladavine” (objavljena 1982. i 1993. u Zagrebu).

Bio je profesor crkvene povijesti na Teologiji u Rijeci (1971.-2000.), generalni vikar Riječko-senjske nadbiskupije (1993.-1996.) te upravitelj Sakralne baštine u Senju (1985.-2000.). 1999. godine imenovan je pomoćnim riječko-senjskim biskupom sa sjedištem u Gospiću, a 2000. godine postaje prvi gospićkosenjski biskup.

Organizator je brojnih znanstvenostručnih skupova. Objavio je pet knjiga i devedeset znanstvenih članaka. Područja njegova znanstvena interesa su: povijest biskupija Senjske i Modruške ili Krbavske (napose onoga dijela koji je ušao u sastav Gospićko-senjske biskupije) i hrvatski glagolizam (hrvatska glagoljska kultura). Za znanstveni rad 1996. godine odlikovan je Redom Danice hrvatske s likom Marka Marulića, a 1995. godine dobio je Nagradu Grada Senja.

\section{ČERNELIĆ, MILANA, dr.sc. izv.prof.}

Rođena je 1954. godine u Osijeku. Maturirala je u gimnaziji u Somboru 1973. godine. Diplomirala je engleski jezik i književnost i etnologiju na Filozofskom fakultetu u Zagrebu, kada je i izabrana za stručnog suradnika na Odsjeku za etnologiju na istom fakultetu. Obranila je magistarsku radnju s naslovom Tradicije svatovskih časti, njihovi nazivi i uloge, sosobitim obzirom na pojave i uloge staćela na Filozofskom fakultetu u Zagrebu. Doktorsku disertaciju s naslovom Odabrane pojave iz svadbenih običaja bunjevačkih Hrvata kao izvor za proučavanje njihove etnogeneze obranila je 1997. godine na Filozofskom fakultetu u Zagrebu. U srpnju 2006. godine izabrana je u znanstvenonastavno zvanje izvanrednog profesora. Od 2002. do 2006. godine bila je voditeljica znanstvenoga projekta "Identitet i etnogeneza primorskih Bunjevaca", a od 2008. vodi znanstveni projekt "Identitet i etnokulturno oblikovanje Bunjevaca".

Uže područje njezina znanstvenoga interesa u okviru nacionalne etnologije su pojave iz duhovnoga i društvenoga života (običaji, obitelj - zadruge, problemi etničkih grupa), a u novije vrijeme uloga etnologa u razvoju ruralnoga turizma. Ta su istraživanja napose vezana uz istraživanja identiteta i etnogeneze hrvatske etničke grupe Bunjevci. 


\section{ČILAŠ ŠIMPRAGA, ANKICA, dr.sc.}

Rođena je 1970. godine u Kninu. Nakon završenoga studija jugoslavenskih jezika i književnosti na Filozofskom fakultetu u Zagrebu radila je na Hrvatskoj radioteleviziji kao lektor, a od rujna 1997. zaposlena je u Institutu za hrvatski jezik i jezikoslovlje u Zagrebu. Magistrirala je 2002. godine s temom Fonologija ikavskih štokavskih govora izmedu rijeka Krke i Neretve, a doktorirala 2006. godine obranivši disertaciju pod naslovom Antroponimija i toponimija Promine. Radi kao znanstvena suradnica na projektu Onomastička i etimologijska istraživanja hrvatskoga jezika te objavljuje znanstvene radove iz onomastike i dijalektologije.

\section{DRONJIĆ, MATIJA}

Rođen je 1984. godine u Karlovcu. Apsolvent je arheologije i etnologije s kulturnom antropologijom na Filozofskom fakultetu Sveučilišta u Zagrebu. Glavno područje njegova istraživačkog interesa predstavljaju: narodni život, vjerovanja i običaji dinarskoga područja, te općenito duhovni aspekti materijalne kulture, pučka etimologija i usmena književnost.

\section{LJUBOVIĆ, BLAŽENKA, prof.}

Rođena u obitelji Prpić, 1951. godine u Senju. Osnovnu školu završila je u Krivom Putu, gimnaziju u Senju, a studij arheologije i povijesti na Filozofskom fakultetu u Zadru, čime je stekla zvanje profesora povijesti i arheologije. Nakon dugogodišnjega profesorskoga rada u srednjoj školi od 1997. godine do danas zaposlena je u Gradskom muzeju Senj gdje obnaša dužnost ravnateljice i obavlja poslove višeg kustosa.

U sklopu svoga muzejskoga rada vršila je arheološka istraživanja, konzervatorske i zaštitne radove te pripremila više autorskih i suautorskih izložaba na razne teme. Svoje pisane radove na temu bogate senjske kulturne baštine objavila je u raznim stručnim časopisima i katalozima izložbi. Član je više različitih društava i udruga u kulturi na području grada Senja i šire. Dobitnica je Povelje Grada Senja za poseban doprinos u razvoju muzejsko-galerijske djelatnosti i promidžbu bogate kulturnopovijesne baštine grada Senja.

\section{LJUBOVIĆ, ENVER, prof.}

Rođen je 1950. godine u Obrama - Kakanj, Bosna i Hercegovina. U Zadru je završio Filozofski fakultet, grupu povijest i latinski jezik s pregledom rimske književnosti. Trideset godina radi kao gimnazijski profesor latinskog jezika i povijesti, stalno zaposlen u Srednjoj školi dr. Antuna Barca u Crikvenici. Kao vanjski suradnik predaje latinski jezik u Srednjoj školi Pavla Rittera Vitezovića u Senju.

Dugi niz godina bavi epigrafikom, toponomastikom, onomastikom, heraldikom i rodoslovljem obitelji. Iz toga je znanstvenoga područja objavio pet knjiga i više stručnih članaka u Hrvatskoj, Bosni i Hercegovini te Italiji. Predsjednik je Senjskog književnog ognjišta, udruge koja promiče hrvatski jezik i kulturu i afirmira književno stvaralašvo u Senju i šire. Stalni je suradnik Leksikografskog zavoda "Miroslav Krleža”, s člancima o hrvatskim plemićkim obiteljima. Član je Hrvatskog društva klasičnih filologa te dobitnik Povelje Grada Senja za doprinos u prosvjeti, kulturi i znanosti. Stalno je nastanjen u Senju, gdje živi s obitelji.

\section{RAJKOVIĆ, MARIJETA, prof.}

Rođena je 1976. godine u Sisku. Diplomirala je etnologiju i povijest 2003. godine na Filozofskom fakultetu Sveučilišta u Zagrebu. Godine 2004. upisuje poslijediplomski doktorski studij etnologije i kulturne antropologije na istom fakultetu i trenutno je apsolvent (izrađuje doktorsku disertaciju). Od 2004. godine zaposlena je kao asistentica/znanstvena novakinja na Odsjeku za etnologiju i kulturnu antropolo- 
giju na Filozofskom fakultetu u Zagrebu. Središte njena znanstvenog interesa čine: ekonomske migracije, etničke manjine, konstrukcije identiteta i ruralni turizam. Sudjelovala je na dva međunarodna i dva hrvatska znanstvena projekta. Autorica je desetak znanstvenih i stručnih radova.

\section{RUBIĆ, TIHANA, prof.}

Rođena je 1978. godine u Zagrebu. U ožujku 2004. godine diplomirala je povijest umjetnosti i etnologiju na Filozofskom fakultetu Sveučilišta u Zagrebu, gdje je iste godine upisala i poslijediplomski studij etnologije i kulturne antropologije. Tijekom studija sudjelovala je u terenskim istraživanjima u okviru znanstvenog projekta Identitet i etnogeneza primorskih Bunjevaca, voditeljice dr. sc. Milane Černelić. Od 2007. godine zaposlena je kao znanstvena novakinja na Institutu za etnologiju i folkloristiku u Zagrebu, na znanstvenom projektu Suvremeni kulturni tijekovi i oblikovanje zajednica $i$ identiteta, voditeljice dr. sc. Jasne Čapo Žmegač. U sklopu zajedničkog dvogodišnjeg etnomuzikološkog istraživanja proučava glazbu manjinskih etničkih i vjerskih zajednica u Hrvatskoj, te priprema doktorsku disertaciju. Tajnica je Hrvatskog etnološkog društva (HED) (od 2005.) i suorganizatorica Ljetne škole HED-a (od 2004.), članica Međunarodnog savjeta za tradicijsku glazbu (ICTM), te bivša polaznica i povremena suradnica Centra za ženske studije Zagreb.

\section{ŠARIĆ, MARKO, mr.sc.}

Rođen je 1971. godine u Zagrebu. Od 1992. do 1998. pohađao dvopredmetni studij povijesti i poljskog jezika i književnosti na Filozofskom fakultetu Sveučilišta u Zagrebu. Diplomirao 1998. s temom "Društveni odnosi i previranja u sandžaku Lika-Krka u 16. i početkom 17. stoljeća”. Od 1998. pohađao poslijediplomski studij povijesti na Filozofskom fakultetu u Zagrebu i 2005. magistrirao s temom "Dinarski Vlasi između Osmanskog Carstva i Venecije: povijest pravnih institucija jednog krajiškog društva (15.-17. st.)". Od svibnja 2001. zaposlen je kao znanstveni novak na Zavodu za hrvatsku povijest Odsjeka za povijest Filozofskog fakulteta u Zagrebu. Od 2001. do 2007. tajnik je Međunarodnog istraživačkog projekta “Triplex Confinium”, a danas suradnik na projektu "Triplex Confinium: hrvatska višegraničja u euromediteranskom kontekstu”. Specijalistički interes usmjeren je na povijest Jugoistočne Europe ("Zapadni Balkan”) u ranome novom vijeku (16.-18. st.) s posebnim naglaskom na povijest graničnih društava i kultura u prostoru imperijalnog višegraničja (tzv. "Tromeđa”).

\section{ŠARIĆ ŽIC, IVANA, prof.}

Rođena je 1973. godine u Zagrebu. 1999. godine diplomirala je na Filozofskom fakultetu Sveučilišta u Zagrebu; studij povijesti i etnologije. Od 2000. godine zaposlena je u Ministarstvu kulture, Upravi za zaštitu kulturne baštine, Konzervatorski odjel u Rijeci. Stekla je zvanje konzervatora - višeg stručnog savjetnika. 2002. godine upisuje Poslijediplomski znanstveni studij etnologije i kulturne antropologije. Područje njezina znanstvenostručnog interesa čine tradicijska arhitektura i teme iz tradicijskoga gospodarstva (s naglaskom na maslinarstvo i stočarstvo). 